\title{
Job satisfaction and work-family policies through work-family enrichment
}

\author{
Angel Martinez-Sanchez, Manuela Perez-Perez, \\ Maria-Jose Vela-Jimenez and Silvia Abella-Garces \\ Direccion y Organizacion de Empresas, Universidad de Zaragoza, \\ Zaragoza, Spain
}

Job satisfaction and workfamily policies

Received 3 December 2017 Revised 27 April 2018 6 July 2018

Accepted 9 July 2018

\begin{abstract}
Purpose - The purpose of this paper is to analyze the effect of a bundle of work-family policies on employee's job satisfaction and (affective) organizational commitment, by using work-family enrichment and conflict as explanatory.

Design/methodology/approach - Empirical study is conducted with a sample of 322 employees from 30 Spanish firms that have been granted with the "Flexible Firm Award" or have been certified as "Family Responsible Firms." Structural equation modeling is used to test hypotheses.

Findings - The results show that the higher the use of work-family policies the more positive effects on work-family enrichment and conflict, and that job satisfaction is positively related to (effective) organizational commitment.

Research limitations/implications - This is a cross-sectional study which may limit the establishment of causal relationships.

Practical implications - Work-family policies may constitute a relevant management tool to balance work and family life by making employees more interested in their jobs, enhancing their well-being and reducing the conflicts between work and family domains. The positive role of work-family enrichment contributes to enhance employees' job satisfaction and, at the same time, to increase their organizational commitment. Managers should pay attention at how work-family policies are justified because they may influence differently on their outcomes on satisfaction and commitment.

Originality/value - There are two main original contributions of the paper. First, the authors study the joint effect of work-family policies on different dimensions of enrichment and conflict. Second, the authors analyze the relationship between different dimensions of enrichment and conflict on job satisfaction and organizational commitment.
\end{abstract}

Keywords Work family issues, Organizational commitment, Job satisfaction

Paper type Research paper

\section{Introduction}

Among the many requirements that may contribute to employees' job satisfaction and organizational commitment, balancing work and family responsibilities is not a minor one. A negative work-family interface may jeopardize the human resource management efforts that develop committed employees who contribute to the firm's competitive advantages. Consequently, considerable efforts have been exerted to analyze the effects of work-family policies from different perspectives.

Besides the more known perspective of conflict, there is another one that also helps to explain the relationship between work-family policies and employees' job satisfaction and organizational commitment, but it has been less empirically tested (McNall, Nicklin and Masuda, 2010; McNall, Masuda and Nicklin, 2010; Zhang et al., 2018). This other perspective is enrichment that, as opposed to conflict, does not emphasize that sharing activities (work and family) is always restraining but positive and sometimes rewarding. What an employee learns at work may positively influence his/her family life. Similarly, the personal

There is no potential conflict of interest in this study. The research has been funded by a Grant (ECO2010-19704) from the Spanish Ministry of Science, Education and Innovation.

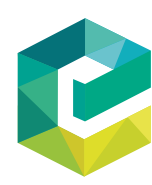

Journal of Managerial Psychology (C) Emerald Publishing Limited $0268-3946$ 
development of an individual with family responsibilities may motivate him/her to become a better professional. For instance, individuals who are more patient with children at home may have better work relationships with colleagues; similarly, conflict resolution skills learned at work may help resolve conflicts at home.

The evidence so far shows that enrichment and conflict are conceptually and empirically different concepts, although they may be related (Carlson et al., 2010; McNall, Nicklin and Masuda, 2010; McNall, Masuda and Nicklin, 2010). The use of enrichment, without demeaning conflict, might improve our knowledge about how work-family policies contribute to job satisfaction and organizational commitment. This combination of different perspectives would be aligned with the current interest of scholars to develop integrated models (Baral and Bhargava, 2010) that analyze the interactions between work-family interfaces and employees output. However, empirical studies have scarcely combined enrichment and conflict (e.g. Gareis et al., 2009) and we have not found any multivariate analysis of enrichment, conflict, and employees' job satisfaction and organizational commitment. This scarcity of such studies could explain the inconclusive results found in the literature.

Based on these limitations, our research intends to contribute to the literature on work-family policies, work-family interfaces, job satisfaction and organizational commitment by adopting new approaches. First, against the common single work-family practice approach we model work-family policy as a multidimensional bundle of practices. Casper and Harris (2008) suggest that the effect of policy implementation on employees' affective commitment may depend on what other policies are already offered by the organization. Therefore, it could be a useful contribution for managers to know if the synergic effects among different work-family policies have stronger effects on the work-family interface than the influence of single policies. Are work-family policies significantly related to all dimensions of conflict and enrichment when a bundle of policies is analyzed instead of single ones?

Second, we model the work-family interface as multidimensional by including not only conflict but enrichment as well: enrichment is important because of its beneficial effects on balancing work and family, and conflict because balancing may reduce it. This double perspective of conflict and enrichment would be a useful contribution to managers if they wish to develop family-friendly environments. Which is better? Focusing efforts to reduce sources of conflict or to stimulate sources of enrichment that improve employees' job satisfaction and organizational commitment?

Third, we analyze in our model the relationship between job satisfaction and organizational commitment, which is actually the dependent variable of the study, after analyzing the links of enrichment and conflict with job satisfaction. Other studies consider job satisfaction and organizational commitment to be direct outputs of the work-family interface. However, the study of a more interrelated model by making organizational commitment the dependent variable would help managers to understand that paying attention to the work-family interface is positive not only to employees but also to firms because highly committed employees are better job performers (Riketta, 2002). These three main contributions of our new integrated approach could also help to explain some inconclusive previous results in the literature. Managers could find new arguments to justify the adoption of work-family policies according to their improvement of the work-family interface and the impact on employees' satisfaction and organizational commitment.

Our research contributes additionally by studying Spanish firms because there are some differences in the Spanish culture for work and family policies in comparison with Anglo-Saxon countries. In the USA, and perhaps a few other nations, researchers who are interested in the ways organizations affect the work-family interface have turned away from investigating organizational policies in favor of studying employee perceptions of the "family supportiveness" of the organization or the supervisor (Wayne et al., 2013). This 
is largely because the USA does not federally mandate any family-friendly workplace policies. The Spanish context offers a scenario with relatively more family friendliness at the policy level: for instance, there are Spanish foundations and non-profit institutions that acknowledge and award family-friendly firms (e.g. www.masfamilia.org); similarly, labor internal-flexibility issues are formally negotiated and included in collective agreements between trade unions and employers; and at the regional or national level, legislation and conciliation plans of working and family life even exist. However, there are also some obstacles and contradictions that make work-family balance a difficult task in Spain: for example, Spanish working hours are something atypical, in comparison with the USA or Northern European countries, because of a long lunch break that translates into late returning home; at the same time some women have to leave the labor market to assume family responsibilities due to difficult schedules and the lack of kindergarten facilities. However, despite this situation, Spain has one of the lowest birth rates in the world. The Spanish context offers a more complex setting that could complement other studies in Anglo-Saxon countries.

The broad objective of our research is then to study the relationships between workfamily policies, work-family enrichment and conflict, job satisfaction and affective organizational commitment in a Spanish sample. Our specific contributions are as follows: the study of a bundle of work-family policies instead of a single-practice approach, the combination of enrichment and conflict as work-family interface to analyze which one is more significantly related to job satisfaction, the analysis of job satisfaction and affective organizational commitment as interrelated outputs instead of direct outputs of the work-family interface, and the setting of the research in a Spanish context. The paper is structured as follows. The next section develops the theoretical background, research model and hypotheses. Then we explain the research methodology followed by the results. Finally, we present a discussion of results and implications, and we end with conclusions and limitations.

\section{Theoretical background and hypotheses}

\section{Work-family interface theories}

Although the work-family interface is grounded in different theories, our model is based on the resource-based view (RBV) and dynamic capabilities theory (Barney, 1991; Teece et al., 1997) complemented by social exchange theory (Blau, 1964) because they offer an integrative theoretical framework for our research. According to the RBV, the firm's intangible resources are more difficult to imitate and replicate by competitors. Among intangible resources, human resource management is an idiosyncratic feature for each company. Although work-family policies could a priori be very similar between companies, it is how companies manage them what constitutes a resource difficult to imitate. This intangible may contribute to, for example, a greater organizational commitment in those companies whose employees are more satisfied with the work-family policies. Similarly, according to social exchange theory, employees may feel obligated to exert "extra" effort in compensation for "extra" benefits from work-family policies. Therefore, both capability and social exchange theories indicate that the implementation of work-family policies as a component of a family-friendly human resource management system may positively contribute to the firm's competitive advantage. This management system cannot be easily imitated by competitors because many intangible components are involved. Additionally the propositions derived from both theories point out to the same reciprocity from employees as recipients of the work-family policies. This integrated framework would help to explain the relationship between the adoption of work-family policies and job satisfaction and organizational commitment.
Job satisfaction and workfamily policies 


\section{Work-family policies}

We now focus on work-family policies and why analyzing a bundle of them is important. Work-family policies are separate human resource policies, such as flexi-time, which may or may not have been implemented with the objective of facilitating work-family balance, but which the literature recognizes as having a positive influence (De Sivatte et al., 2015). Even though several work-family policies exist, our study focuses on those related to work organization (flexi-time, hours-pool, etc.) because they are the most adequate to influence job satisfaction and (affective) commitment. For instance, firms may adopt flexi-time to facilitate the entrance or exit of employees to pick up kids at school and give them schedule flexibility.

We believe that there is synergy among a bundle of policies, and therefore, we propose an integrated analysis with enrichment and conflict. For example, policies like flexi-time and hours-pool may reinforce each other because an employee can increase his/her hourspool if he/she arrives earlier to work or exits later. The joint use of some work-family policies may facilitate work organization and then enhance their beneficial effects on employees' multiple roles (Selvarajan et al., 2013). For example, telework and sharing jobsites between employees may be mutually reinforced as long as they facilitate the availability of employees during specific time slots for meetings. This approach is consistent with the tradition of focusing on a range of bundle policies in the research of human resources. For instance, Casper and Harris (2008) suggest that the effect of implementing schedule flexibility on employee's affective commitment may depend on what other policies were also offered.

The synergy created by a work-family bundle may also hamper imitation. According to the RBV and capabilities theory, resources provide sustained competitive advantages if they are not easily imitated. A work-family bundle is more difficult to imitate because some policies are mandatory by law, but others are not. The management of work-family issues is in any case something complex. Many factors influence the transformation of a firm to a "great place to work" from a family-friendly perspective, and it takes time to build a work-family bundle, which is rare among firms: some policies, like flexi-time, are common, but a comprehensive set is not. Hence, we focus our research on a bundle of policies.

\section{Research hypotheses}

The work-family interface has traditionally focused on conflict because its analysis seeks solutions to negative situations facing employees (Bennett et al., 2017). However, the enrichment perspective is also useful (Gareis et al., 2009). Although enrichment and conflict may look as two separate and opposite concepts, the reviewed studies are not conclusive in terms of their relations (Greenhaus and Powell, 2006; Gareis et al., 2009; Zhang, Yip, Chi, Cheung and Zhang, 2012; Carlson et al., 2013). According to Greenhaus and Powell (2006), work-family enrichment happens when resources obtained in one role (personal or labor) improve, either directly through the performance in another role (instrumental route) or indirectly through the influence on positive affects (affective route). For instance, enrichment is produced when a mother/father who is a manager uses the same method of dialogue or negotiation with children at home to advise his/her subordinates (instrumental route), or when a travel agent who returns home satisfied because he/she has achieved sales targets at work shows him/herself more collaborative at home (affective route). These situations describe examples where role accumulation does not produce losses of resources but even net gains that can be used in any role. Similar to conflict analysis, enrichment is bidirectional, which means that benefits can be obtained from work and applied to family (W-F enrichment) or can be derived from family and applied to work ( $\mathrm{F}-\mathrm{W}$ enrichment).

Work-family policies may contribute to enrichment either the affective or the instrumental route, because they can give employees more control over their schedules or 
how they perform their jobs (Lövhöiden et al., 2011; Nicklin and Mcnall, 2013). For example, policies like flexi-time may give employees a sensation of control over their work-family interface, thus enhancing positive attitudes at work that can be transferred to positive affects at home. Even those individuals who do not use work-family policies would perceive that the organization cares about employees and enrich their work experience. Therefore, we propose the following:

H1a. The use of work-family policies is positively related to $\mathrm{W}-\mathrm{F}$ enrichment.

H1b. The use of work-family policies is positively related to $\mathrm{F}-\mathrm{W}$ enrichment.

The perspective of conflict has been studied more (Byron, 2005; Michel et al., 2010). Work-family policies may reduce conflict, and some studies show that employees at family-friendly firms perceive that labor does not interfere with family responsibilities (Selvarajan et al., 2013). For example, flexi-time may smooth the strain-based W-F conflict (Green et al., 2011), whereas part-time contracts or telework may diminish time-based W-F conflict by reducing the time spent at the company facilities. In the other direction, $\mathrm{F}-\mathrm{W}$ conflict, work-family policies may compensate the perception of family members about the employee's work schedule (Wayne et al., 2013). Having more flexibility at home to organize family activities may facilitate a flexible behavior at work. However, our review also indicates that although work-family policies reduce conflict, the results are not always conclusive and are usually based on analyses of single policies (Carlson et al., 2013). By incorporating a work-family bundle we expect to find more conclusive pieces of evidence. Thus, we propose the following:

H2a. The use of work-family policies is negatively related to $\mathrm{W}-\mathrm{F}$ conflict.

$H 2 b$. The use of work-family policies is negatively related to $\mathrm{F}-\mathrm{W}$ conflict.

According to social exchange theory and some previous studies, work-family policies may enhance job satisfaction (Bui et al., 2016). Our research proposes that enrichment and conflict may explain employees' behavior. Regarding enrichment, the performance of multiple roles may be beneficial to individuals because they have to develop skills in stressful environments, which may give them satisfaction in return when the job is done. We argue that the work-family enrichment that results from this accumulation of resources at work leads to individuals' positive feelings about their own work (more job satisfaction).

Regarding conflict, the literature indicates that W-F conflict reduces job and personal satisfaction and increases psychological stress, whereas $\mathrm{F}-\mathrm{W}$ conflict diminishes efficiency. Some studies directly propose reducing $\mathrm{W}-\mathrm{F}$ conflict to increase job satisfaction (Zhang, Griffeth and Fried, 2012) because when employees perceive that organizations are family-friendly, their levels of $\mathrm{W}-\mathrm{F}$ conflict diminish. Other studies even find that a bad work-family interface makes employees quit which means that employees with lower W-F conflict are likely to be more satisfied at work (Carlson et al., 2013). Thus, we propose the following:

H3a. W-F enrichment is positively related to job satisfaction.

H3b. F-W enrichment is positively related to job satisfaction.

$H 4 a$. W-F conflict is negatively related to job satisfaction.

$H 4 b . \mathrm{F}-\mathrm{W}$ conflict is negatively related to job satisfaction.

Finally we propose a direct relationship between job satisfaction and organizational commitment which is the degree to which an employee is loyal to his/her organization. 
According to recent studies and meta-analyses in the literature (Meyer et al., 2002; Frenkel et al., 2013; Valaei and Rezaei, 2016), job satisfaction is positively related to organizational commitment, although other researchers find that job satisfaction and organizational commitment are direct outputs of the work-family interface (Chen, 2004). We follow the first line of research instead of considering commitment as another output of the work-family interface because we focus our analysis on affective commitment. Allen and Meyer (1990) and Meyer and Allen (1991) developed a three-component model of organizational commitment: affective, continuance and normative. We focus on affective commitment because according to Allen and Meyer (1990), it is "the most prevalent approach to organizational commitment in the literature" (p. 2), and because we want to highlight that employees who wish to remain in the organization are those that desire to do it and not because they need or ought to do so (continuance and normative commitments). Affective commitment implies positive feelings toward the organization, whereas job satisfaction means positive feelings toward a job position. Positive feelings are more related to the affective gains and losses caused by W-F enrichment and conflict, which may influence job satisfaction. While an employee is satisfied with his/her job, he/she may be more prone to have positive feelings toward the organization, its values, and its objectives. According to social exchange theory, employees may feel obligated to exert "extra" effort in compensation for "extra" benefits from work-family policies. At the same time, these employees may value very positively the satisfaction derived from their present job position and feel in turn more affectively committed to the organization. However, employees may not be only satisfied in their present job positions just because of the greater enrichment or lower conflict due to the use of work-family policies. Consequently, we do not propose a direct relationship between enrichment and conflict with organizational commitment because other important job factors such as salary may influence commitment. Therefore, job satisfaction may positively influence affective commitment if employees have reasons to be satisfied at the affective level in their job positions. We consider that work-family enrichment and conflict have direct influences at the affective level on job satisfaction, and therefore, it is this positive affection that may produce greater commitment to the organization. Thus, we propose the following:

H5. Job satisfaction is positively related to (affective) organizational commitment.

\section{Methodology \\ Sample}

Data for this study were obtained by a survey aimed at employees from the population of Spanish firms that had obtained a "Flexible Firm Award" organized by the company CVALORA in the period 2002-2013. This award is an initiative of this company (www. cvalora.com/), starting in 2002, that attempts to detect and spread the best flexible practices in the company. It is a referent in terms of management and has the support of private enterprises, communication media, business schools and regional governments in Spain. Companies certified as "family-responsible companies" (EFR) are also included. The initiative EFR, developed by the Mas Familia (More Family) Foundation (www.masfamilia. org/), has been recognized as good practice for the United Nations. It responds to a new labor culture and socio-based flexibility, mutual respect and commitment through private certification. Both initiatives are the most important in Spain regarding the visibility of those firms that are family-friendly and best places to work (www.greatplacetowork.es/). Our study includes the last 30 firms that had been recognized by the CVALORA's award or the EFR certificate in previous years. We did not include more ancient firms to make sure that all firms in our sample were family friendly at the time of the survey. Older firms might have diminished their commitment to family friendliness from the time of the awards. 
We realized that our sample may look family-friendly biased, but it is also a fact that some work-family policies are mandatory by law in Spain (e.g. parental leave). This means it is not possible to have a sample control of firms without work-family policies. Nevertheless, the study of family-friendly firms is most suitable to our model because their organizational context is more homogeneous in terms of informal support from employees' work supervisors and colleagues.

The survey was conducted during the last quarter of 2012 using a structured questionnaire. The final number of valid questionnaires was 322 from the 30 firms of our sample. The questionnaires were directly sent to employees by their own firms through the intranet. Given that our sample of firms is limited in number, we decided to have more than one observation per firm. Having more than one observation per firm enables us to analyze the individual differences of employees since our study assesses subjective perceptions of the work-family interface in a homogeneous context of organizational support toward family friendliness. The average time taken by employees to fill out the questionnaire was $30 \mathrm{~min}$. The response rate was 38 percent regarding the number of employees who were using or needed to use work-family policies in their firms. The mean number of responses per firm was approximately 11 employees, and the sample was evenly distributed in a balanced demographic group between men and women but with family situations of children and elders in care. We wanted to have a largely balanced distribution of surveyed employees because of the strong movement nowadays in Spain for women's equal labor rights and opportunities to break the salary gender gap and the "ceiling glass" (the Spanish salary gender gap in 2016 was 12 percent, above the 11 percent gap of the EU-28; Germany and France gaps were 8 percent and 7.5 percent, respectively, whereas Finland and Sweden gaps were below 5 percent). Table I shows basic statistics from the sample.

\begin{tabular}{|c|c|c|}
\hline Characteristic & Mean & SD \\
\hline Gender $^{\mathrm{a}}$ & $\begin{array}{c}55.4 \% \text { female } \\
44.6 \% \text { male }\end{array}$ & - \\
\hline Employees with partner ${ }^{\mathrm{a}}$ & $78.9 \%$ & - \\
\hline Employees with children $^{\mathrm{a}}$ & $61.8 \%$ & - \\
\hline Number of children living at home & 0.6 & 0.86 \\
\hline \multicolumn{3}{|l|}{ Employees with children living at home } \\
\hline Under 6 years old & $26.7 \%$ & 0.44 \\
\hline $6-16$ years old & $15.2 \%$ & 0.36 \\
\hline $16-18$ years old & $3.1 \%$ & 0.17 \\
\hline Older than 18 years & $3.7 \%$ & 0.19 \\
\hline \multicolumn{3}{|l|}{ Number of children living at home } \\
\hline Under 6 years old & 1.33 & 0.49 \\
\hline $6-16$ years old & 0.64 & 0.67 \\
\hline $16-18$ years old & 0.91 & 0.30 \\
\hline Older than 18 years & 1.07 & 0.88 \\
\hline Employees with elder care responsibilities $^{a}$ & $28.5 \%$ & - \\
\hline Employees with children or elder care responsibilities & $52.2 \%$ & - \\
\hline Age (years) ${ }^{a}$ & 40 & 7.72 \\
\hline Live in urban area & $93 \%$ & - \\
\hline Years in the firm ${ }^{\mathrm{a}}$ & 10.1 & 7.77 \\
\hline Years in present job position & 6.6 & 6.38 \\
\hline \multirow[t]{2}{*}{ Sector $^{\mathrm{a}}$} & Services $80.1 \%$ & - \\
\hline & Industry $19.9 \%$ & \\
\hline
\end{tabular}

Job satisfaction and workfamily policies 
The variable "work-family policies" has been measured as the mean of the use of the following 11 policies: telework, flexi-time, part-time fixed contract, to share a job site with another employee, possibility to reduce the working day, intensive working day anytime, intensive working day in the summertime, compressed workweeks, personal or family leaves, short holidays/leaves, and hours-pool. These are the "good practices" proposed by the Spanish government to facilitate conciliation of work and family life in firms and public institutions (Ministerio de Sanidad y Política Social, 2009). Therefore, they are included in our study because of their Spanish focus even though these policies are found in other studies, such as flexi-time, telework, or part-time contracts (Anderson et al., 2002; Breaugh and Frye, 2008; Casper and Harris, 2008; De Sivatte and Guadamillas, 2013). The variable "work-family policies" takes values between 0 and 1 . This type of variable that measures the average use of a bundle of human resource management practices has also been used previously in other studies (e.g. Escrig-Tena et al., 2012). Employees were asked to mark which policies they had used or were using at the time of the survey. A higher value of this variable indicates a greater use of work-family policies and a greater synergy effect because they can facilitate more the work-family interface. The measurement of this variable is different from the other variables of our multivariate analysis to reduce common method bias.

Enrichment was measured with the 18-item construct adapted from Carlson et al. (2006). Example of an item: "My involvement in my work helps me to understand different viewpoints and this helps me be a better family member."

Conflict was measured with the 10-item construct adapted from Netemeyer et al. (1996). Example of an item: "The amount of time my job takes up makes it difficult to fulfill family responsibilities."

Job satisfaction was measured with the 5 -item construct adapted from Anderson et al. (2002). Example of an item: "The work I do on my job is meaningful to me." Organizational commitment was assessed with the 8 items adapted from Allen and Meyer (1990) but only for affective commitment as we explained before. Example of an item: "I would be very happy to spend the rest of my career with this organization." These four variables were measured with a seven-point Likert scale from 1 "totally disagree" to 7 "totally agree."

We control for some individual variables: gender (dummy, 1 female and 0 male), dependence (dummy, 1 there are elder relatives to care and 0 otherwise), job hierarchy (seven-point Likert scale, from 1-lowest base to 7-top management) and area of residence (dummy, 1 urban and 0 rural).

\section{Methods}

Given that having one single informant to answer questionnaires is a threat of common method variance (CMV), we used several strategies to minimize it. First, we took care to allow the respondents' answers to be anonymous and assured them that there was no right or wrong answer and that they should give honest answers. This procedure reduces people's evaluation apprehension to answer independently from any researcher's expectation (Podsakoff et al., 2003). We also randomized the order of the questions in such a way that hampers CMV across variables. In the construction of the items, we defined all terms, gave examples when needed, and kept questions simple. Besides being careful at designing the survey instrument, we also conducted the Harman one-factor test: a single factor did not emerge, and the first one accounted for 14.8 percent of the total variance. However, Harman's one-factor test cannot consistently produce an accurate conclusion about CMV levels (Fuller et al., 2016; Williams and McGonagle, 2016). For CMV statistical assessment, we first examined a confirmatory factor analysis (CFA) model that included the six latent variables measured with multiple indicators (W-F enrichment and conflict, job satisfaction and organizational commitment); we then added a method factor latent variable 
with paths to all indicators of the latent variables to represent a source of CMV. This method variance model showed a very little improvement in fit $\left(\chi^{2}=1533.7(613) p=0.00 ; \chi^{2}\right.$ diff $(1)=7.9$; comparative fit index $(\mathrm{CFI})=0.891$; root mean square error of approximation $(\mathrm{RMSEA})=0.074 ; p<0.05)$, but the median amount of method variance in the 41 indicators was only 7 percent. In addition, for the five key factor correlations associated with the model, the differences in their values associated with CMV were very small (being 0.04 the largest difference in correlation value). Thus, although we found evidence of very small amounts of CMV, it did not account for any meaningful amount of the shared variance among the latent variables that are the core part of the research model and its proposed relationships (according to Fuller et al., 2016, for typical reliabilities of scales, CMV would need to be on the order of 70 percent or more before substantial concern about inflated relationships would arise). These findings indicate that CMV is not a likely alternative explanation for our results. Finally, to control for nonresponse bias, we compared the earlier and later respondents, but we did not find statistical significant differences in terms of work-family interface or demographics.

Prior to data collection, we checked the content validity of the items and pretested the survey instrument with academics and practitioners. After data collection, we evaluated the dimensionality, reliability and discriminant validity of our scores. Even though these scales have been used before, this was the first time they were used together in a Spanish sample, and so we wanted to ensure our scores' reliability despite translation, back-translation and adaptation of the items. Exploratory factor analysis (EFA) and CFA confirmed the composition of scales. EFA indicates that job satisfaction and (affective) organizational commitment are single constructs, whereas enrichment and conflict have two dimensions each: W-F enrichment (nine items), F-W enrichment (nine items), W-F conflict (five items) and F-W conflict (five items); the factor loadings of items are above 0.7 in all cases. Reliability analyses indicate that Cronbach's coefficient $\alpha$ exceeds 0.85 for all constructs, and average variance extracted (AVE) exceeds 0.5 , which indicates satisfactory simple reliability. Composite reliability (CR) also exceeds the suggested minimum of 0.7 . Construct validity was examined through the adequacy of the model's fit and both convergent validity and discriminant validity. CFA was used to test the model's fit and the results were satisfactory; a model is considered to be satisfactory if the CFI is at least 0.95 (Hu and Bentler, 1999) and the RMSEA is less than 0.08 . All tests for discriminant validity were similarly supportive; specifically, the square roots of the AVE values for the latent constructs were found to be greater than the correspondent correlations. Table II shows means, standard deviations and correlations that are high between some constructs; Table III reports the Cronbach's $\alpha$, AVE and CR for the constructs; and Table IV indicates the CFA.

To test our hypotheses, we use structural equation modeling with method robust maximum likelihood that can accommodate data assumed to be missing at random. We did not use hierarchical linear modeling because the intraclass correlation coefficient showed high values $(>0.9)$ in all cases considering two-way mixed and absolute agreement analysis. EFA was carried out with SPSS software version 19, and CFA with EQS software, version 6.1 for Windows.

\section{Results}

Figure 1 shows the results of our model. The goodness of fit statistics show validity since $\mathrm{CFI}$ and NNFI are closed to 0.95 , RMSEA is below 0.05 , and the relative $\chi^{2}$ is less than 3 although we report $\chi^{2}$ values.

The use of work-family policies is positively related to enrichment but negatively related to conflict, which supports $H 1 a, H 1 b, H 2 a$ and $H 2 b$. Regarding the relationship with job satisfaction, our results show differences. Enrichment and conflict are only significantly related to job satisfaction in the work-family direction (positive for enrichment and negative 
JMP

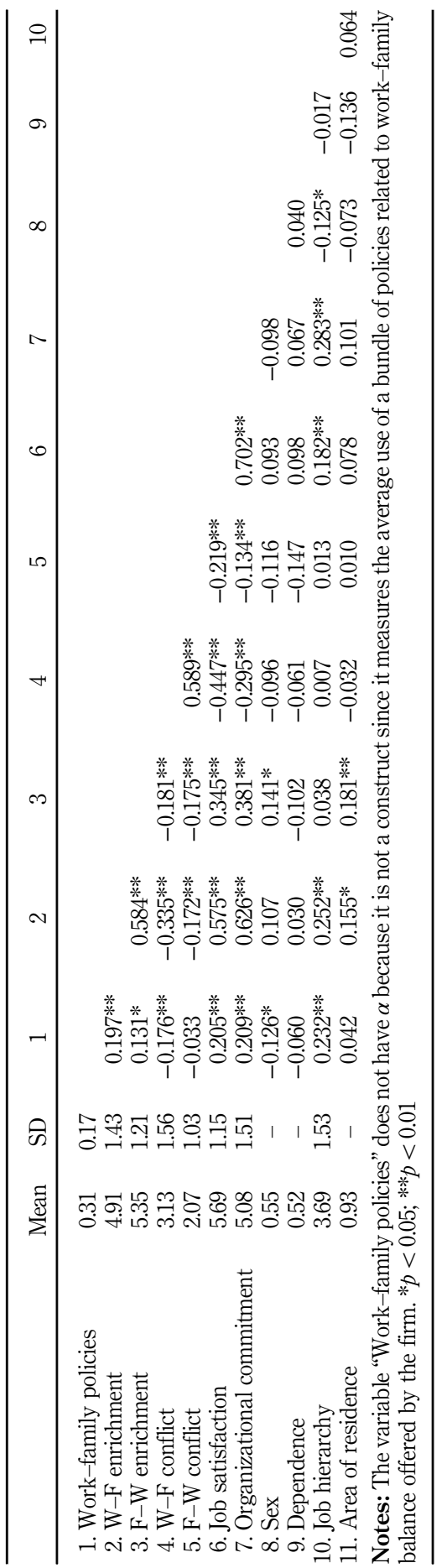

Table II.

Descriptive statistics

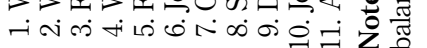




\begin{tabular}{lcccc}
\hline Variable & Cronbach's $\alpha$ & AVE & CR & $\begin{array}{c}\text { Job satisfaction } \\
\text { and work- }\end{array}$ \\
\hline W-F enrichment & 0.973 & 81.32 & 0.96 & 0.95 \\
F-W enrichment & 0.954 & 74.45 & 0.94 \\
W-F conflict & 0.933 & 54.28 & 0.86 \\
F-W conflict & 0.854 & 68.18 & 0.88 \\
Job satisfaction & 0.869 & 78.64 & 0.96 \\
Organizational commitment & 0.955 & &
\end{tabular}

Notes: AVE, average variance extracted; $C R$, composite reliability. The variable "work-family policies" does not have AVE or CR because it is not a construct since it measures the average use of a bundle of policies related to work-family balance offered by the firm

Table III.

Reliability coefficients

\begin{tabular}{lrcccrr}
\hline & $\chi^{2}$ S-B & Relative $\chi^{2}$ S-B & RMSEA & NNFI & CFI & \\
\hline Enrichment & 546.43 & 2.8 & 0.041 & 0.939 & 0.929 & \\
Conflict & 73.17 & 2.1 & 0.045 & 0.963 & 0.972 & Table IV. \\
Job satisfaction & 13.08 & 2.6 & 0.041 & 0.956 & 0.978 & Coefficients of good-fit \\
Organizational commitment & 46.96 & 3.2 & 0.046 & 0.964 & 0.976 & measurement models \\
\hline
\end{tabular}

for conflict), which supports $H 3 a$ and $H 4 a$ but does not validate $H 3 b$ and $H 4 b$. Job satisfaction is positively related to organizational commitment, which supports H5. Regarding control variables, hierarchy and area of residence are positively related to work-family policies, whereas gender and dependence are not significant.

Figure 1 also reveals that $\beta$ coefficients for enrichment exceeded those for conflict in both the work-to-family and the family-to-work directions, although the last direction is not statistically significant. Thus, for family-friendly firms, enrichment seemed especially salient in explaining the relationship between work-family policies and job satisfaction.

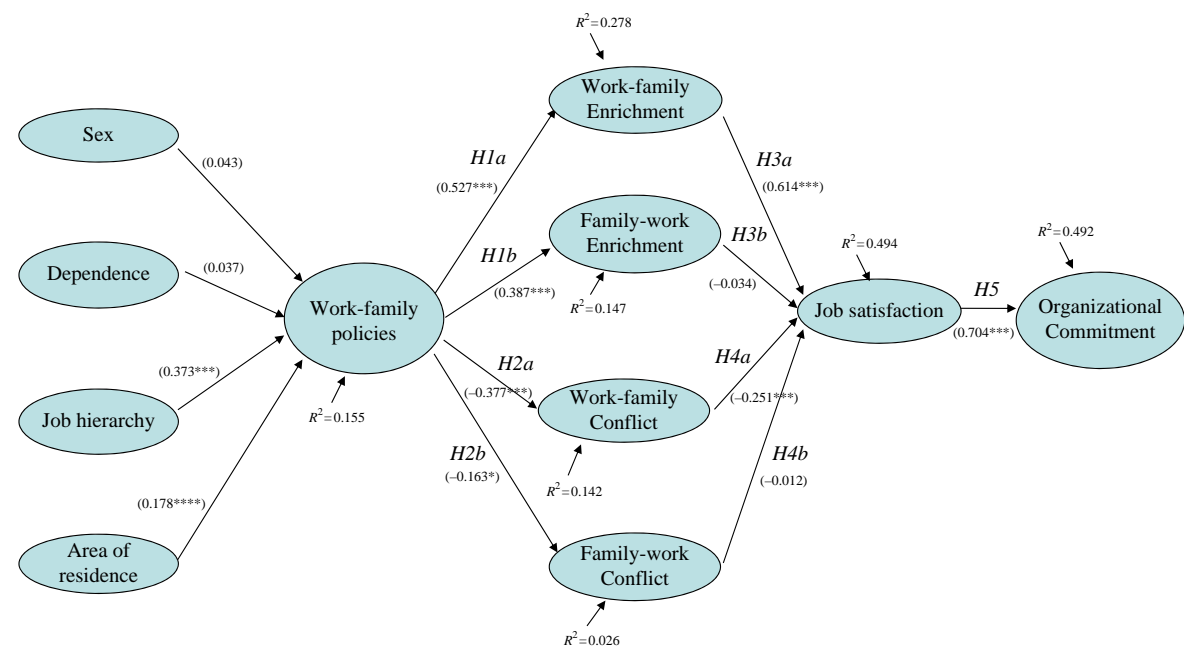

Notes: $\chi^{2}=2,678.17$; Relative $\chi^{2}$ (Satorra-Bentler) $=2.2 ; \chi^{2} p$-value $=0.00 ;$ RMSEA $=0.045$; $\mathrm{CFI}=0.940 ; \mathrm{NNFI}=0.931 . * p<0.05 ; * * *<<0.001 ; * * * * p<0.1$
Figure 1.

Job satisfaction goodfit structural model with standardized estimates 
Similarly, Figure 1 indicates that the $\beta$ coefficients between work-family policies and enrichment exceeded those for any relationship with conflict.

Besides the direct effects of $\mathrm{W}-\mathrm{F}$ enrichment and conflict on job satisfaction depicted in Figure 1, some of the other depicted variables have indirect effects on job satisfaction and organizational commitment. First, "work-family policies" $(\beta=0.421 p<0.001)$ and "job hierarchy" $(\beta=0.157 p<0.01)$ have significant positive indirect effects on job satisfaction. Second, there are four variables with significant indirect effects on organizational commitment: work-family policies $(\beta=0.297 p<0.001)$, work-family enrichment $(\beta=0.436 p<0.001)$, work-family conflict $(\beta=0.177 p<0.001)$ and the control variable of job hierarchy $(\beta=0.110 p<0.05)$.

\section{Discussion}

These results make several contributions to the literature. First, the bundle approach responds to the research limitations and mixed results of analyzing single policies and partial models (Breaugh and Frye, 2008; Carlson et al., 2013; Selvarajan et al., 2013). In our model, work-family policies are significantly related to all dimensions of enrichment and conflict, which could indicate that a bundle approach captures better than a single approach the cross-domain and within-domain effects of policies even though within-domain effects are more statistically significant than cross-domain effects. Second, we have incorporated the full dimensionality of enrichment and conflict (work-family and family-work), whereas other studies focus on either conflict or enrichment (e.g. McNall, Nicklin and Masuda, 2010). Our results support those studies that suggest that employees who use work-family policies experience less conflict and are more satisfied at work (Breaugh and Frye, 2008). Similarly, the availability of appropriate policies communicates that the organization is family-friendly, cares about employees and is a great place to work. The statistically significant indirect effect of work-family policies on job satisfaction reinforces the importance of the bundle approach because it can consider a more diverse and complete range of influences on job satisfaction.

Besides this theoretical side of the discussion there are also several managerial implications. First, our results indicate that enrichment may be a more explanatory variable than conflict to analyze the relationship between work-family policies and job satisfaction. We have found that whether in the $\mathrm{W}-\mathrm{F}$ direction or in the $\mathrm{F}-\mathrm{W}$ direction, the beta coefficient that links enrichment and job satisfaction is above the coefficient of conflict. This means that enrichment explains a larger variance of job satisfaction than conflict and it suggests that it would be better to use or to do not demean at least- enrichment to explain the contribution of work-family policies to job satisfaction. Besides the direct effect on job satisfaction, the indirect effect of $\mathrm{W}-\mathrm{F}$ enrichment on organizational commitment is also greater than the indirect effect of W-F conflict. These findings support other studies that highlight the importance of including measures of work-family enrichment because they provide incremental explanatory power over work-family conflict alone (Gareis et al., 2009). In our research, enrichment is a key variable that indicates the strength of the link between work-family policies and job satisfaction.

Our research suggests that the support of the family environment becomes crucial in the achievement of personal enrichment and a positive work environment. On the one hand, employees may contribute to improving the work-family interface by involving closer family members in the design and adoption of lifestyles to plan their future labor priorities. On the other hand, organizations should value the implementation of any policy that supports employees at home. Supervisors and employees alike should be aware that affection has implications to manage positive roles at work and in the family. Employees may feel satisfied by worrying about colleagues at work as well as by being involved in the development of teamwork activities through work-family policies that help them compensate work stress. 
A second important managerial implication is that the perspective of enrichment offers a more favorable view than conflict to link managerial actions and employees' performance. The skills acquired using work-family policies may generate greater trustfulness that can be useful to make employees feel better at work. At the same time, they contribute to their personal development and employability. Managers should be aware of the importance of developing a positive working environment that supports employees with, for instance, greater work-family enrichment.

Employees who use work-family policies may take more advantage of what they learn at the workplace. Skills and achievements at the workplace offer experiences that may positively influence the family environment. This gives more sense to the job and makes employees feel more satisfied about the opportunities their job may offer. By correctly performing tasks in the workplace, employees may understand different views which enriches family relations and influences job satisfaction.

This managerial implication also goes beyond job satisfaction because it is positively related to organizational commitment. Our research has found several significant relationships (work-family policies, enrichment, conflict and job satisfaction) that eventually lead to a positive link between job satisfaction and affective organizational commitment. These results may suggest a causal relationship that would be worthy to analyze in a future longitudinal-data study. Nevertheless affective commitment is significantly related to all other study variables (Table II), which is not the case for other variables. If employees feel more satisfied at work because they experience greater $\mathrm{W}-\mathrm{F}$ enrichment and lower $\mathrm{W}-\mathrm{F}$ conflict due to the use or availability of work-family policies, then they may be, as a consequence, more affectively committed to the organization. It is important that employees can feel attachment to their organizations if they are going to be asked to exert extra efforts; otherwise, they will not be willing to contribute to the organization beyond their strict job obligations.

Our results suggest that work-family policies may be a way to achieve affective organizational commitment because enrichment contributes to making employees more satisfied in their job positions and exert "extra" effort in return. For instance, individuals with more satisfactory family and work roles may protect themselves more from the potential negative effects of each role and keep a healthier mental and physical attitude. Although employees may feel tired after work they may also feel enjoyment by accomplishing their tasks. Firms might leverage even more positively the effect of work-family policies on commitment by facilitating those resources that convey work-family enrichment.

Finally, we discuss why $H 3 b$ and $H 4 b$ have not been supported. The lack of support may suggest that despite our bundle approach of policies that are significantly related to all dimensions of enrichment and conflict, the influence of family over work may produce less job satisfaction (cross-domain effect) than with the positive and significant association of the work-family direction (within-domain effect). An apparent case of negative statistical suppression happened here. Despite being significantly positively correlated $(r=0.345)$, the path coefficient between $\mathrm{F}-\mathrm{W}$ enrichment and job satisfaction $(\beta=-0.034)$ is negative and not significant. Another statistical suppression effect seems to be behind $H 4 b$ as well (F-W conflict and job satisfaction). The family over work path (cross-domain effect) loses its predictive power when taken together with the within-domain effect in the multivariate analysis. Nevertheless, our findings are similar to other studies. The recent meta-analysis of Zhang et al. (2018) about work-family enrichment found that the within-domain effect of W-F enrichment on job satisfaction is greater than the cross-domain effect of $\mathrm{F}-\mathrm{W}$ enrichment. The resources flowing from work to family may differ from those flowing from family to work more generally, not just in terms of the specific measures included in our constructs. For instance, Carlson et al. (2006) found that work and family had some type of domain-crossing resources in common (e.g. intellectual and personal development) but other resources were 
uniquely associated with work-to-family (e.g. a source of accomplishment) vs family-to-work (e.g. time management). According to our constructs, a closer examination of the $\mathrm{F}-\mathrm{W}$ enrichment items indicates that most items are related to behavioral traits such as being happy, glad, or in a good mood. Therefore, we could ask ourselves why W-F enrichment is not significantly related to job satisfaction even though a bundle of work-family policies is positively related to both $\mathrm{W}-\mathrm{F}$ and $\mathrm{F}-\mathrm{W}$ enrichment.

The results in Figure 1 indicate that work-family policies are more strongly related to the work-to-family direction of enrichment and conflict (within-domain effect) than to the family-to-work direction (cross-domain effect). This means that work-family policies may influence more strongly the employees' cognitive and behavioral mechanisms of $\mathrm{W}-\mathrm{F}$ enrichment and conflict. Thus, employees can be in a better mood among family members due to the support of work-family policies on their working activities, and this positive effect influences more strongly job satisfaction than the positive effect from the family-to-work direction. This would be understandable because work-family policies are aimed to modify behaviors at work by, for instance, reorganizing schedules. Work-family policies can modify cognitive and behaviors at work more than at home, and that is why enrichment and conflict are significantly related to job satisfaction along the work-to-family direction but not along the family-to-work direction. It is not an easy task for traditional work-family policies to influence cognitive and behavioral mechanisms at the family domain since they are basically implemented to enhance or correct such mechanisms at work. Perhaps the importance of family quality time could be indirectly enhanced by traditional policies but they should be complemented by other initiatives such as open-door working days organized for company workers and their families.

\section{Conclusions, limitations and future research}

This study has analyzed an integrated model of relationships between work-family policies, enrichment, conflict, job satisfaction and affective organizational commitment. Our results indicate that work-family policies may constitute a relevant management tool for the work-family interface by focusing on enrichment and making employees more interested in their jobs and enhancing their well-being. Having highly satisfied and motivated employees may be a success factor for the future of the firm. Additionally, jobs are enriched by allowing employees to acquire greater responsibilities and functions, increasing the variety of learning but also making work-family policies available to employees to help them better to organize their time.

If employees can develop skills to solve conflict at work that can also be used to solve family conflicts, it would positively influence their psychological well-being and as a consequence, job satisfaction. Thus, the enrichment of employees will eventually contribute to affective organizational commitment, and in turn the organization would benefit from less absenteeism or increased productivity.

Our study supports the need to adopt work-family policies to improve job satisfaction and organizational commitment. The positive effect of these policies is justified by the enrichment that employees experience in their work-family interface. This result constitutes a contribution within the dynamics of human resource management that has traditionally focused on conflict. However, emphasizing enrichment allows including more employees in the management of human resources, and not only those with situations of conflict. The management of human resources should be oriented to a greater variety of job performance outputs if we want to visualize the potential synergy within different work-family policies.

The conclusions of our study should be analyzed according to its limitations. First, we have used perception measures that are not totally free of response bias. Second, our measures are for a single unit of time that cannot test causal relationships. Future studies 
could collect longitudinal data to assess the dynamic effects of work-family policies. They could also analyze if job satisfaction mediates the relationship between work-family policies and organizational commitment or if conflict and enrichment mediate the relationship between work-family policies and job satisfaction.

\section{References}

Allen, N. and Meyer, J. (1990), "The measurement and antecedents of affective, continuance and normative commitment to the organization", Iournal of Occupational Psychology, Vol. 63 No. 1, pp. 1-18.

Anderson, S.E., Coffey, B.S. and Byerly, R.T. (2002), "Formal organizational initiatives and informal workplace practices: links to work-family conflict and job-related outcomes", Iournal of Management, Vol. 28 No. 6, pp. 787-810.

Baral, R. and Bhargava, S. (2010), "Work-family enrichment as a mediator between organizational interventions for work-life balance and job outcomes", Lournal of Managerial Psychology, Vol. 25 No. 3, pp. 274-300.

Barney, J. (1991), "Firm resources and sustained competitive advantage", Journal of Management, Vol. 17 No. 1, pp. 99-120.

Bennett, M.M., Beehr, T.A. and Ivanitskaya, L.V. (2017), "Work-family conflict: differences across generations and life cycles", Journal of Managerial Psychology, Vol. 32 No. 4, pp. 314-332.

Blau, P. (1964), Exchange and Power in Social Life, Wiley, New York, NY.

Breaugh, J. and Frye, N. (2008), "Work-family conflict: the importance of family-friendly employment practices and family-supportive supervisors", Journal of Business and Psychology, Vol. 22 No. 4, pp. 345-353.

Bui, H.T.M., Liu, G. and Footner, S. (2016), "Perceptions of HR practices on job motivation and work-life balance: mixed drives and outcomes in a labor-intensive sector", International Iournal of Manpower, Vol. 37 No. 6, pp. 1004-1023.

Byron, K. (2005), "A meta-analytic review of work-family conflict and its antecedents", Lournal of Vocational Behavior, Vol. 67 No. 2, pp. 169-198.

Carlson, D.S., Grzywacz, J.G. and Kacmar, K.M. (2010), "The relationship of schedule flexibility and outcomes via the work-family interface", Journal of Managerial Psychology, Vol. 25 No. 4, pp. 330-355.

Carlson, D.S., Grzywacz, J.G. and Zivnuska, S. (2013), "Is work-family balance more than conflict and enrichment?", Human Relations, Vol. 62 No. 10, pp. 1459-1486.

Carlson, D.S., Kacmar, K.M., Wayne, J.H. and Grzywacz, J.G. (2006), "Measuring the positive side of the work-family interface: development and validation of a work-family enrichment scale", Journal of Vocational Behaviour, Vol. 68 No. 1, pp. 131-164.

Casper, J. and Harris, Ch.M. (2008), "Work-life benefits and organizational attachment: self-interest utility and signaling theory models", Journal of Vocational Behavior, Vol. 72 No. 1, pp. 95-109.

Chen, L.Y. (2004), "Examining the effect of organization culture and leadership behaviors on organizational commitment, job satisfaction, and job performance at small and middle-sized firms of Taiwan", Journal of American Academy of Business, Vol. 5 No. 1, pp. 432-438.

De Sivatte, I. and Guadamillas, F. (2013), "Antecedents and outcomes of implementing flexible policies in organizations", The International Journal of Human Resource Management, Vol. 24 No. 7, pp. 1327-1345.

De Sivatte, I., Gordon, J., Rojo, P. and Olmos, R. (2015), "The impact of work-life culture on organizational productivity", Personnel Review, Vol. 44 No. 6, pp. 883-905.

Escrig-Tena, A.B., Bou-Llusar, J.C., Roca-Puig, V. and Beltrán-Martín, I. (2012), "Does quality management drive labour flexibility?", Total Quality Management, Vol. 23 No. 2, pp. 159-176.

Frenkel, S., Sanders, K. and Bednall, T. (2013), "Employee perceptions of management relations as influences on job satisfaction and quit intentions", Asia Pacific Journal Management, Vol. 30 No. 1, pp. 7-29. 
Fuller, Ch.M., Simmering, M.J., Atinc, G., Atinc, Y. and Babin, B.J. (2016), "Common methods variance detection in business research", Journal of Business Research, Vol. 69 No. 8, pp. 3192-3198.

Gareis, K.C., Barnett, R.C., Ertel, K.A. and Berkman, L.F. (2009), "Work-family enrichment and conflict: additive effects, buffering, or balance?", Journal of Marriage and Family, Vol. 71 No. 3, pp. 696-707.

Green, S.G., Bull Schaefer, R.A., MacDermid, S.M. and Weiss, H.M. (2011), "Partner reactions to work-tofamily conflict: cognitive appraisal and indirect crossover in couples", Journal of Management, Vol. 37 No. 3, pp. 744-769.

Greenhaus, J.H. and Powell, G.N. (2006), "When work and family are allies: a theory of work-family enrichment", Academy of Management Review, Vol. 31 No. 1, pp. 72-92.

Hu, L.T. and Bentler, P.M. (1999), "Cutoff criteria for fit indexes in covariance structure analysis: conventional criteria versus new alternatives", Structural Equation Modeling, Vol. 6 No. 1, pp. 1-55.

Lövhöiden, C., Yap, M.H.P. and Ineson, E.M. (2011), "Work-family conflicts and enrichment in the Norwegian hotel industry", Scandinavian Journal of Hospitality and Tourism, Vol. 11 No. 4, pp. 457-482.

McNall, L.A., Masuda, A.D. and Nicklin, J.M. (2010), "Flexible work arrangements, job satisfaction, and turnover intentions: the mediating role of work-to-family enrichment", The Journal of Psychology, Vol. 144 No. 1, pp. 61-82.

McNall, L.A., Nicklin, J.M. and Masuda, A.D. (2010), "A meta-analytic review of the consequences associated with work-family enrichment”, Journal Business Psychology, Vol. 25 No. 3, pp. 381-396.

Meyer, J. and Allen, N. (1991), “A three-component conceptualization of organizational commitment”, Human Resource Management Review, Vol. 1 No. 1, pp. 61-89.

Meyer, J., Stanley, J., Herscovitch, L. and Topolnytsky, L. (2002), "Affective, continuance, and normative commitment to the organization: a meta-analysis of antecedents, correlates, and consequences", Journal of Vocational Behavior, Vol. 61 No. 1, pp. 20-52.

Michel, J.S., Kotrba, L.M., Mitchelson, J.K., Clark, M.A. and Baltes, B.B. (2010), “Antecedents of workfamily conflict: a meta-analytic review”, Journal of Organizational Behavior, Vol. 32 No. 5, pp. 689-818.

Ministerio de Sanidad y Política Social (2009), Guia buenas practicas. Equilibrio de la vida profesional, familiar y personal, Ministerio de Sanidad y Política Social, Madrid.

Netemeyer, R.G., Boles, J.S. and McMurrian, R. (1996), "Development and validation of work-family conflict and family-work conflict scales", Journal of Applied Psychology, Vol. 81 No. 4, pp. 400-410.

Nicklin, J.M. and Mcnall, L.A. (2013), "Work-family enrichment, support, and satisfaction: a test of mediation", European Journal of Work and Organizational Psychology, Vol. 22 No. 1, pp. 67-77.

Podsakoff, P., Mackenzie, S., Lee, J. and Podsakoff, N. (2003), "Common method biases in behavioral research: a critical review of the literature and recommended remedies", Journal of Applied Psychology, Vol. 88 No. 5, pp. 879-903.

Riketta, M. (2002), “Attitudinal organizational commitment and job performance: a meta-analysis”, Journal of Vocational Behavior, Vol. 23 No. 3, pp. 257-266.

Selvarajan, T.T., Cloninger, P.A. and Singh, B. (2013), "Social support and work-family conflict: a test of an indirect effects model", Journal of Vocational Behavior, Vol. 83 No. 3, pp. 486-499.

Teece, D., Pisano, G. and Shuen, A. (1997), “Dynamic capabilities and strategic management”, Strategic Management Journal, Vol. 18 No. 7, pp. 509-533.

Valaei, N. and Rezaei, S. (2016), "Job satisfaction and organizational commitment: an empirical investigation among ICT-SMEs", Management Research Review, Vol. 39 No. 12, pp. 1663-1694.

Wayne, J.H., Casper, W.J., Matthews, R.A. and Allen, T.D. (2013), "Family-supportive organization perceptions and organizational commitment: the mediating role of work-family conflict and enrichment and partner attitudes", Journal of Applied Psychology, Vol. 98 No. 4, pp. 606-622. 
Williams, L.J. and McGonagle, A.K. (2016), "Four research designs and a comprehensive analysis Job satisfaction strategy for investigating common method variance with self-report measures using latent variables", Journal of Business Psychology, Vol. 31 No. 3, pp. 339-359.

Zhang, H., Yip, P., Chi, P., Chan, K., Cheung, Y. and Zhang, X. (2012), "Factor structure and and workfamily policies psychometric properties of the work-family balance scale in an urban Chinese sample", Social Indicators Research, Vol. 105 No. 3, pp. 409-418.

Zhang, M., Griffeth, R.W. and Fried, D.V. (2012), "Work-family conflict and individual consequences", Journal of Managerial Psychology, Vol. 27 No. 7, pp. 696-713.

Zhang, Y., Xu, S., Jin, J. and Ford, M.T. (2018), "The within and cross domain effects of work-family enrichment: a meta-analysis", Journal of Vocational Behavior, Vol. 104 No. 2, pp. 210-227.

\section{Corresponding author}

Angel Martinez-Sanchez can be contacted at: anmarzan@unizar.es

For instructions on how to order reprints of this article, please visit our website: 